\title{
〈解 説〉
}

\section{内分泌摚乱化学物質の試験管内 (in vitro) 試験法}

\section{1. 緒 言}

木材防虫剤は木材防力ビ剤や木材防腐剂とと屯 に木造建築物や木質材料の寿命延長に重要な役割 を果たしている。本分野の薬剤には長期の残効性 が要求される場合が多く，従来はクロルデン等の 有機塩素系の薬剤が用いられてきた。有機塩素郕 は環境中での残留問題もあり使用禁止となり; そ の後，人畜に対し低毒性であり，かつ環境に対す る影響も少ない薬偊としてピレスロイド系殺虫剤 が使われるようになってきた”。ピレスロイド系 殺虫剂の中であべルトリンはその効力と安定性 の高さから, 土壤䞘理用シロアリ防除剂 ${ }^{21}$ の他, 表面処理用木材保存剂や加圧注入用木材保存剂 ${ }^{2 b 31}$ としても広く使用されている。

一方, Colbon博士らの著書(Our Stolen Future : 邦題 “奪われし未来”) $)^{4} の$ 刊行を発端として, 内 分泌擋乱化学物質の問題が大きな社会問題として 取り上げられている。マスコミ等で広く伝えられ ている当該問題を扱った例では，米国でのワ二生 殖器の異常, 日本近海でのイボニシの雌雄同体の 発見, 男子の精子の質・量の低下等があるが, 話 題性に対し，実際は正確な実態把握，原因および 作用メカニズムは未解決の部分が多い5) 7!。

当該問題に早くから取り組んでいる米国環境保 護庁 (EPA)の諮問機関EDSTAC (Endocrine Disruptors Screening and Testing Advisory Committee)もしくはOECD (Organization for Economic Cooperation and Development)では内分 泌擋乱化学物質の判定は最終的には長期動物毒性 試験（繁殖性試験）によることで合意されている。

\section{斎藤幸一，金子秀雄 ${ }^{*}$}

しかし，現在流通する化学物質は 8 万種以上ある と考えられ，てれらの化合物のすべてについて繁 殖性試験を実施することは事実上困難である。そ こで試験管内試験 (in vitro 試験) 上短期動物毒性 試験（in vivo 試験）を用いて優先順位を付け，最 終的には繁殖性試験によって決定していく方針が 示されている。現在, in vitro 試験の目的は, 内分 泌擋乱化学物質がホルモン上密接な関係があるこ とから，(1)ホルモン受容体 (レセプター) と化学 物質の結合性によるホルモンまたは抗ホルモン様 作用の評価，(2)ホルモンの生合成に対する化学物 質の影響評価に大別できる。(1)および(2)の検討に おいて，様々なin vitro試験法が提案されている が、これらの試験方法は未だ検証段階にある。し かし, in vitro試験は, その簡便さ, コス卜等の理 由で広く使用され，それを用いた化学物質の内分 泌擋乱作用を示唆する報告が相次いでなされてい る。てれらの報告が全て䛊りでないにしても，結 果の話題性が先行して, 本来試験法が持つ問題点 を䁔昧にした報告が多数あることは否めないのが 現状である。現在の内分泌摚乱化学物質の大きな 問題は，科学的に十分に検証されていない実験手 法で実施し，さらに得た結果を十分に評価せずに 公表されるためではないかと考える。

本稿では, 内分泌擋乱化学物質の中で最も研究 が進んでいる(1)ホルモン受容体（レセプター）之 化学物質の結合性によるホルモンまたは抗ホルモ ン様作用の評価について, 女性ホルモン（エスト ロゲン) 様化学物質検出のための in vitro 試験法 を中心に概説し，さらにそれらの方法を用いて行 われたピレスロイド系殺虫郕のホルモン様执よび

* 住友化学工業 (株) 生物環境科学研究所 
抗ホルモン様作用試験の結果についても述べる。

\section{2. 内分泌擋乱化学物質の作用点}

内分泌摚乱作用物質の定義は “生体の恒常性, 生殖，発生，あるいは行動に関与する種々の生体 内ホルモンの合成, 貯蔵, 分泌, 体内輸送, 結合 そしてホルモン作用そのもの，あるいはそのクリ アランスなどの諸過程を阻害する作用を持つ外来 性物質”8であり，簡単に言えば“生体内のホルモ ン睘境を擋乱し，毒性作用を惹起するあの”と換 言できる。

まず, ホルモンは, 特定の器官・臓器で産生さ れ，一般に血液で運搬される。そして，標的組織 で特定のレセプター（受容体）と結合し，この結 合により標的細胞内に情報が伝達され，ホルモン 標的遺伝子が活性される。標的遺伝子にはその木 ルモン作用に重要な役割りを担うタンパク質がコ ードされているため, 最終的にはホルモン作用が 発現される。従って, 化学物質がホルモン環境に 与える作用点は，(1)ホルモンとレセプターとの結 合と標的遣伝子の活性化扔よび(2) ホルモンの生合 成・運搬に大別できる（図 1)。

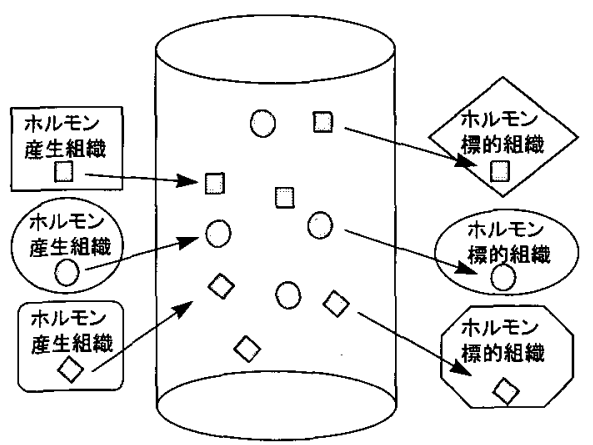

ホルモンの産生 $\Rightarrow$ 血液等での運搬 $\Rightarrow$ ホルモン作用の発現

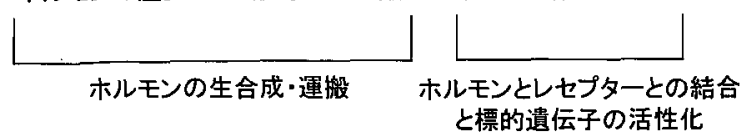

図 1 内分泌擋乱化学物質の作用点

\section{3. 脂溶性ホルモンのレセプター（核内ホル モンレセプター)}

一般的に，ホルモンは水溶性のペプチドホルモ
ンとステロイド等の脂溶性ホルモンに分類できる。 内分泌擋乱化学物質として疑われている化学物質 は比較的低分子な物が多いため，現在は脂溶性小 ルモンを対照とした研究が先行している。脂溶性 ホルモンには，女性ホルモン(エストロゲン)，男 性ホルモン（アンドロゲン）等のステロイドホル モンの他，甲状腺ホルモン等が知られているが， これら脂溶性ホルモンにはそれぞれのホルモンに 対応したレセプターが存在する。こ㧈らのレセプ タ一群は，一般的に“核内ホルモンレセプター” と呼ばれ，非常に部分構造が類似した遺伝子ファ ミリーを形成しているととがわかっている9。

\section{4. 核内ホルモンレセプターの機能}

核内ホルモンレセプターは構造上の類似点の他, ホルモンの機能発現に果たす役割・機構も非常に 類似している。例えばエストロゲンレセプターは 細胞内で，エストラジオール等のホルモンと結合 体を形成し，DNA上に存在する特異配列を認識し て結合する。この特定配列は，一般的にはホルモ ン標的遗伝子の 5'上流側に存在し，ホルモン応答 配列(Hormone responsive element: HRE) と呼ば れている。この特異配列に，各種ステロイドホル モンレセプターはホモ 2 量体, 一方, 甲状腺ホル モン等のレセプターはRXR(レチノイドXレセプ ター)とへテロ 2 量体を形成して結合する ${ }^{9}$ 。そし て，てれらの 2 量体が応答配列に結合すると，リ ガンドーレセプター結合体を認識する一群のタン パク質である転写共役因子(コアクチベーター) ${ }^{101,11)}$ がさらに結合するてとがわかってきている(図 2)。 最近ではコアクチベーターにDNAの構造を弛緩 して遺伝子を転写活性化するヒストンアセチル化 酵素活性が見出され ${ }^{11}$ ，コアクチベーターの役割 りがさらに注目を浴びている。

\section{5. 化学物質とレセプターの結合様式}

化学物質とレセプターの結合には，ホルモン標 的遺伝子の機能発現の観点から 2 種類に分けるこ とができる。それは，化学物質がレセプターと結 合してホルモン様作用を示す場合（アゴニスト作 
(1)ホルモンとレセプターの結合<smiles>C1=CC=C1</smiles>

(2)コアクチベーターの結合<smiles>C1=CC=C1</smiles>

(3)ホルモン標的遺伝子の活性化
ホル
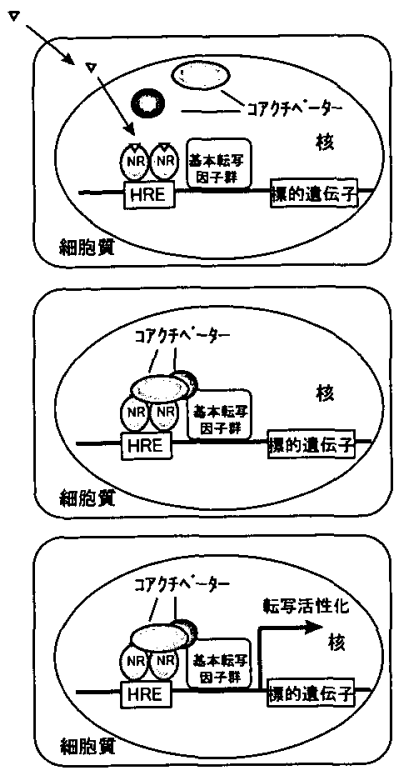

HRE:ホルモン応答配列 NR:核内ホルモンレセプター
図 2 核内ホルモンレセプターの転写活性化のメカニズム
には大きく分けて，1）レセ プター結合試験 (バインディ ングアッセイ，2)培養細胞 增殖アッセイ，3）レポータ 一遗伝子アッセイ，4）酵母 two-hybridアッセイおよび 5）マーカー酵素・蛋白質ア ッセの 5 種類に分類が可 能である。

1) レセプター結合試験 (バインディングアッ セイ)

放射性屯しくは学光標識 したエストロゲンと試験化 合物を共存させて，エスト ロゲンレセプターへの競合 的な結合による標識ホルモ ンの追い出しを測定し，結 合性を知る方法である。試
用）とホルモンの作用をレセプターに結合するこ とにより阻害する場合（アンタゴニスト作用）で ある。アゴニスト扰よびアンタゴニスト作用の分 子メカニズムは未解決の部分が多いが，核内ホル モンレセプターの場合，一般的に，アゴニストは レセプターと結合することにより，上述のコアク チベターと結合し標的遺伝子を活性化するのに対 し，アンタゴニストはレセプターと結合してもコ アクチベーターとの結合が見られない。乙の原因 はレセプターのX線解析等の結果から，アゴニス トはレセプターに結合するとレセプターの立体構 造を変化させ，コアクチベーターとの結合を容易 にするのに対し，アンタゴニストはレセプターに 結合してもアゴニストのような立体構造の变化を 起こさないためと考えられている ${ }^{12) 。 ~}$

\section{6. エストロゲンレセプターに対する試験法}

以下，化学物質のレセプターに対する結合性を 調べる方法について最も研究が進んでいるエスト ロゲンレセプターを例你紹介する。

現在，エストロゲンレセプターに対する試験法
験に用いるエストロゲンレセプターは，通常は奏 験動物の卵巣摘出後の子宮を用い，子宮ホモジェ ネートを調製後に遠心分離して得られたエストロ ゲンレセプター分画を使用する。その他，遺伝子 工学的手法を用いて，例えば，バキュロウイルス を用いた昆虫細胞でエストロゲンレセプターを大 量発現させ調製する場合もある。また，エストロ ゲンレセプターを発現する培養細胞 (MCF-7， $\mathrm{T} 47 \mathrm{D}$ 等）に通常のバインディングアッセイのよ うに培養液中に放射性標識のエストロゲンと試験 化合物を添加してレセプターに対して競合結合さ せた後、レセプターに結合および遊離したホルモ ン量を測定することにより試験化合物とレセプタ 一との結合を知る方法む可能である (whole cell binding assay)。バインディングアッセイは，本 質的にレセプターと化学物質のみを使用するため, 結果に影響を与える因子の関与が少ない長所があ るが，試験化合物にタンパク質変成作用等がある 場合，化合物を高濃度で実験すると競合結合とは 異なる標識ホルモンの追い出し効果を測定するこ とになり䛊った結果を与える。従って，本試験に 
より得られたデー夕を評価する場合には，特に化 合物濃度の設定根拠を注視しなくてはならない。

2）培養細胞增殖アッセイ (E-screen $)^{13)}$

ヒト乳癌由来の培養細胞 MCF-7 は, そのメ力 ニズムは不明であるが，エストロゲン量に依存し て增殖が促進される性質を持っている。従って, MCF-7 亿試験化合物を添加して一定時間後に細 胞数を測定し堌殖度を求めることにより，試験化 合物のエストロゲン様活性を知ることができる。

本法の最大の問題点は, 増殖メカニズムが不明で, 增殖に様々な因子が関与する可能性があり，化学 物質の作用点が不明な点である。例えば，細胞分 裂促進剤等はエストロゲンレセプターに無関係な 作用点に働き增殖を促進するため，乙の方法では 誤った評価を下すとととなる ${ }^{14) 。 ま た, ~ M C F-7 に ~}$ は種々のクローンが存在し ${ }^{15)}$, 細胞の維持方法に よってあ増殖能に違いが起きる場合ああり, 各研 究機関の間で結果の再現性に問題がある。その他， この試験はエストロゲンレセプターのみに有効で あり他のレセプターに対する影響は評価できない。

\section{3）レポーター遺伝子アッセイ}

図 2 に示したホルモンの作用機構に基づき，ホ ルモンがエストロゲンレセプターに結合し標的遺 伝子を活性化する機構を利用した方法である。こ の方法には培養細胞を用いる方法と醉母を用いる

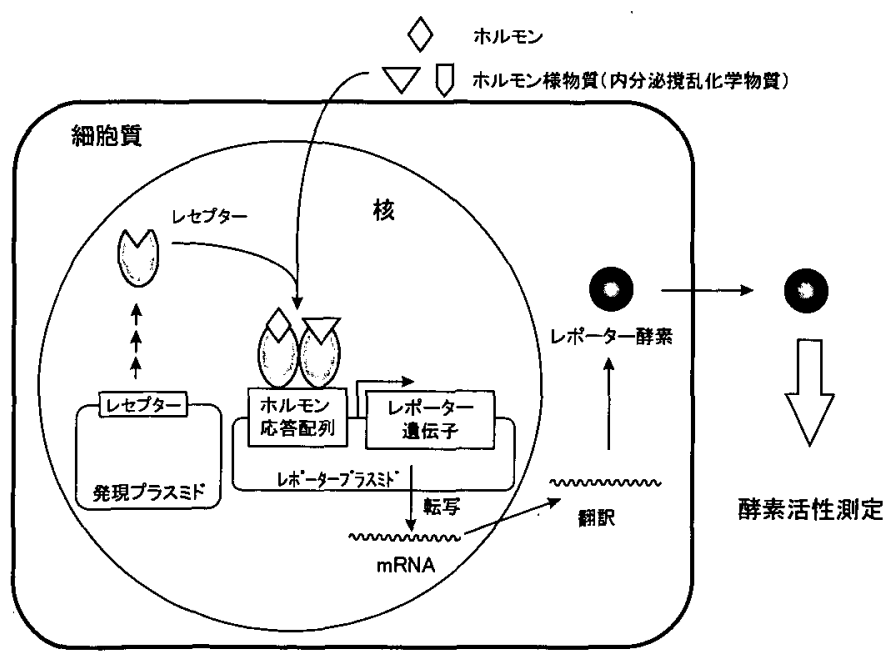

图 3 レポーター遣伝子アッセイの原理
方法がある。

培養細胞を用いる方法では，ヒト子宮頸部癌由 来 $\mathrm{HeLa}$ 細胞やサル腎臓由来 CV - 1 細胞等の培養 細胞にエストロゲンレセプター遺伝子を発現する 環状DNA（プラスミド）とレポータープラスミド を同時に導入する。レポータープラスミドは活性 の指標となる遺伝子(レポーター遺伝子 : ルシフェ ラーゼや $\beta$-ガラクトシダーゼ等の䣲素) の上流に, ホルモン応答配列を挿入したプラスミドを用いる。 細胞内で発現したレセプターにホルモンが結合す ると、レポーター遺伝子の上流にあるホルモン応 答配列に結合して下流にあるレポーター遺伝子の 転写活性化を増大させてレポーター酵素が発現す る。その酵素活性を測定することによりレセプタ 一と化学物質との結合を知ることができる(図 3)。 また，エストロゲンレセプターが細胞内で発現し ているMCF-7やT47D 細胞等を用いる場合はレ ポーター遺伝子のみを導入すればアッセイが可能 となる。

酵母を用いる方法はYES ( Yeast estrogen screen) と呼ばれ，酵母にエストロゲンレセプター 遺伝子遗伝子工学的手法により導入し，培養細 胞と同様にレポーター遺伝子の転写活性を指標に して化学物質の転写活性化能を調べる。醉母に は細胞壁があり化学物質の透過性が哺乳動物細胞 と異なる問題点がある。しかし，酵 母の形質転換株の作製は培養細胞に 比べて著しく容易で，維持等にかか るコストあ安い利点がある。

レポーター遣伝子アッセイの特徵 は感度が高く，作用点のメカニズム が明確であることと，他の核内ホル モンレセプターにあ応用が可能な点 である。

\section{4) 酵母two- hybridアッセイ ${ }^{16)}$}

核内ホルモンレセプターにホルモ ンが結合すると，先述したようにレ セプターの立体構造が变化する ${ }^{11}$ 。 近年, その構造変化を認識してホル モンの結合情報を基本転写因子群に 
A:GAL4の構造

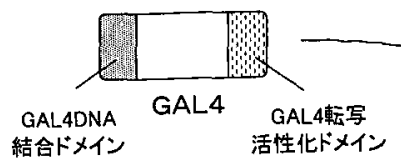

B:Two-hybrid法

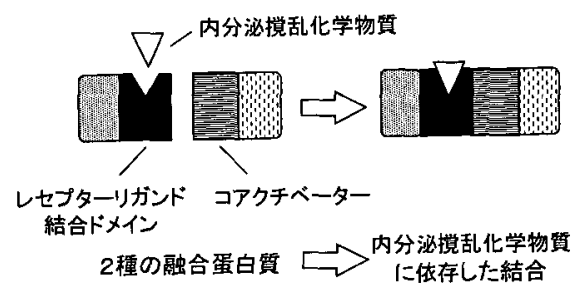

图 4 醉母 Two-hybrid アッセイの原理

伝えるコアクチベーターが発見されてきた ${ }^{10)}{ }^{111}$ 。 本法は,コアクチベーターとレセプターのリガン ド依存的なタンパク質間の相互作用をtwo-hybrid 法により検出する。具体的には図 4 に示すように 酵母内にエストロゲンレセプターと䣲母の転写因 子GAL4のDNA 結合領域の融合タンパク質およ びコアクチベーターとGAL4の転写活性化領域の 融合タンパク質を発現させる。すし醉母内でエス トロゲン様化合物がレセプターに結合すると両融 合タンパク質は結合し，転写因子GAL4の働きを 持つタンパク質が形成される。乙のタンパク質複 合体は転写因子として機能し，レポーター遺伝子 であるß-ガラクトシダーゼを発現する。従って， 化学物質のレセプターとの結合性を $\beta$-ガラクトシ ダーゼ活性で評価することができる。この方法は, 酵母のレポータージーンアッセイに哺乳動物のコ アクチベーターを導入して，さらに哺乳動物の系 に近くなった系でレポーター遺伝子アッセイと同 様，様々な核内レセプターに対して応用が可能で ある。

5）マーカー酵素・蛋白質アッセイ

特殊な培養細胞はエストロゲン様化合物を処理 すると，その細胞特有の酵素やタンパク質が誘導 されるととが知られている。

例えば, Ishikawa Ver-1 細胞はエストロゲンを 加えるとアルカリフォスファターゼが誘導される ${ }^{17\}}$
しかし，ての方法はメカニズムの不明な特 殊な細胞の特殊な現象に基づいているため 現在はあまり使用されない。

\section{7. in vitro 試験法の比較と問題点}

上記の 5 種の in vitro 試験法はそれぞれ 特徴を有しているが, EPAのEDSTAC等の 評価から，最も推薦されているのはレセプ ター結合性試験（バインディングアッセイ） とレポーター遺伝子アッセイである。てれ は両アッセイが高感度で, 作用点およびメ カニズムが明確であるからである。酵母 two-hybridアッセイは近年開発された方法 で世界的に実施例は多くはないが，感度， メカニズムの明確さから言えば上記雨試験に近い 物と考えられる。しかし，乙れら全ての in vitro 試験に共通な問題点は，試験に用いる化学物質の 濃度である。細胞を使用するアッセイ（細胞系） では細胞毒性と試験化合物の溶解度の検討により 適切な濃度設定が必要であるが，残念ながら，か なりの内分泌摚乱関連 in vitro 試験でこの点が曖 昧にされている。特に，化合物に細胞毒性があれ ば，アンタゴニストと同様な結果を与えるために 偽陽性の結果が出てしまう。細胞を用いない試験 (非細胞系) でも，化合物の溶解度と界面活性/ 蛋白変成作用の検討がなければ正しい評価はでき ない。特に，高濃度の試験化合物のバインディン グアッセイ結果については溶解度を含めて結果の 解析に注意が必要である。以上のように, in vitro 試験は簡便で，動物試験よりあ廉価で，実施しや すいのは事実であるが，実験条件に十分注意を払 わないと，評価を誤る可能性がある。

\section{8. in vitro試験の実際}

我々は上記の in vitro 試験の問題点等を考慮し て，ピレスロイド系殺蛳8剂(d-trans-アレス

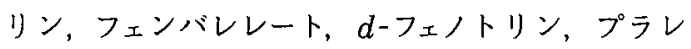
スリン, エンペントリン，ペルメトリン，シペル メトリン，イミプロトリン)のエストロゲン18), 19), アンドロゲン ${ }^{191}$ 执よびプロゲステロン ${ }^{19), 201}$ レセ 
プターに対するホルモン様扝よび抗ホルモン様作 用を検討した。試験方法としてはメカニズムが最 6明確なレセプター結合性試験（バインディング アッセイ)、レポーター遺伝子アッセイおよび酵母 two-hybridアッセイを選択した。

培養細胞を用いたレポーター遺伝子アッセイに おいては最初に適切な化合物濃度の設定実験を行 った。まず，細胞毒性等を検出するために作製し たレポーター遺伝子を恒常的に発現するコントロ 一ル細胞に各種化合物を加え，レポーター遺伝子 発現に与える影響濃度を検討した。また，培地中 の化合物の培解度を濁度で測定した。その結果, 最高適用濃度は $1 \sim 10 \mu \mathrm{M}$ と決定された。それら の濃度で，ホルモン様および抗ホルモン作用を検 討したが，試験の有効性を検証する陽性対照化合 物は全て陽性結果が得られたのに対し，いずれの
ピレスロイド殺虫剤もホルモン様および抗ホルモ ン様作用は認められなかった。

レセプター結合性試験（バインディングアッセ イ）抢よび酵母 two-hybridアッセイに打いては化 合物の溶解度を指標に適切な化合物適用濃度を設 定し検討を行ったが，いずれのピレスロイド殺虫 剤も検討した 3 種のレセプターに対してホルモン 様および抗ホルモン様作用は認められなかった。 この結果は, エストロゲンおよびアンドロゲンレ セプターに関しては既に報告されている陰性結果 と同様であった21,22)

図 5 亿具体例としてペルメトリンのエストロゲ ンレセプターの結果を示す。図5-Aに示すよう にアゴニストであるエストラジオールやアンタゴ ニストの4-ヒドロキシタモキシフェンはエストロ ゲンレセプターに結合するのに対しペルメトリン
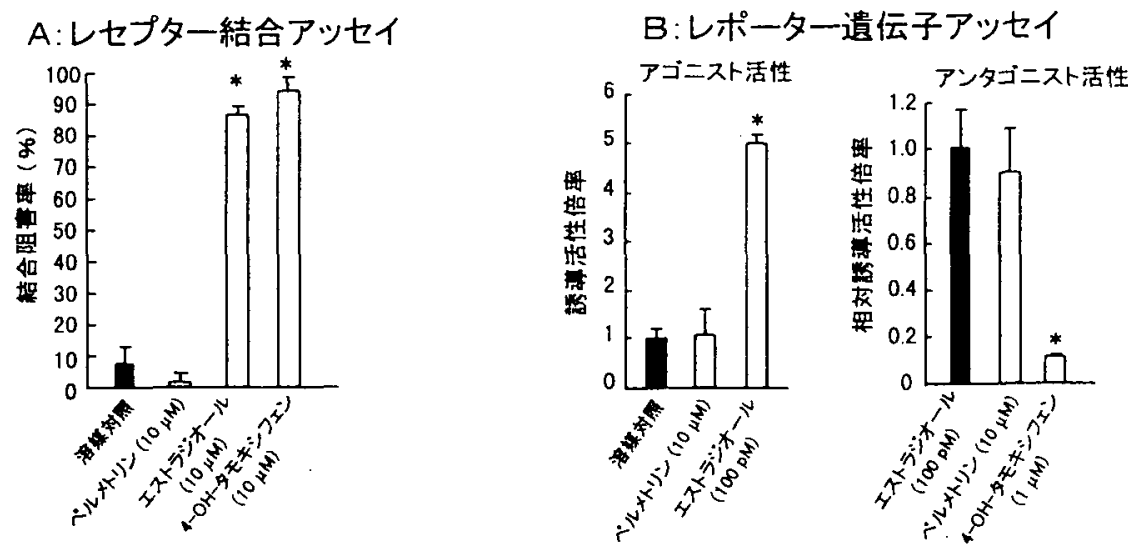

C:醉母wo-hybridアッセイ
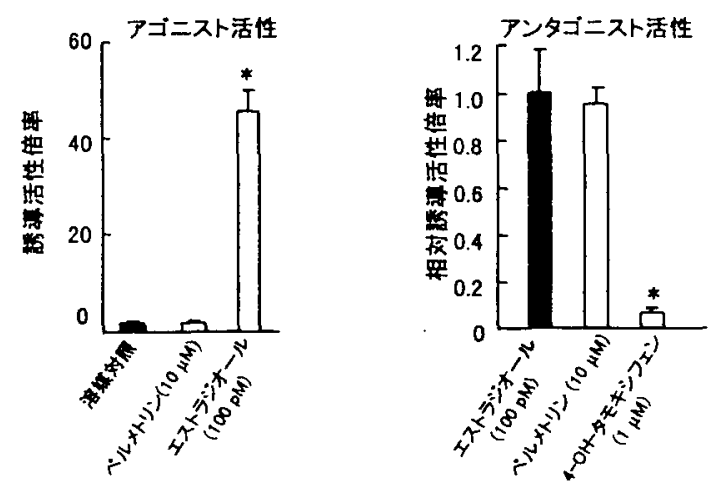

*: $\propto \times 0.05$

有等落有り

図 53 種の in vitro アッセイを用いたエストロゲンおよび抗エストロゲン様作用の評価例 
では結合活性は認められない。また，図5-Bおよ びCに示すようにペルメトリンにはエストロゲン レセプターを介したアゴニストおよびアンタゴニ スト活性は全く認められなかった。

\section{9. おわりに}

現在, 内分泌擋乱化学物質を評価するために様 々な in vitro 試験が提唱されているが，それぞれ

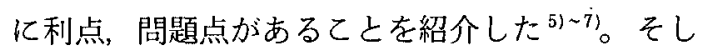
て，その問題点を補い信頼性を向上するには，例 えば,レセプター結合性試験(バインディングア ッセイ)、レポーター遺伝子アッセイ、酵母 twohybridアッセイのようなメカニズムの明らかなin vitro 試験を複数組み合わせて評価するてとが有効 であると考えられる。そてで,てれら 3 種の in vitro 試験を用いて，ピレスロイド系殺虫剤 8 種のホル モン様および抗ホルモン様作用について検討した が，いずれの化合物もそのような作用を示さなか った。

また，今回詳しく述べなかったが，一般的に化 学物質は生体内に入ると薬物代謝酵素により多く の代謝物に変換されることが知られている。従っ て，親化合物にはホルモン様活性がなくても，生 体内で代謝反応を受けてホルモン様活性を有する ようになる化合物が存在する7。しかし，現存す る多くのin vitro 試験は代謝活性化を考慮できず, 代謝物の作用を調べることが出来ない。そこで, 現在, Ames 試験と同様の考えから肝臓薬物代謝 醉素画分で前処理をする方法が考案されているが 検証段階である ${ }^{23), 24 ! 。 ~}$

以上のように, in vitro試験什化学物質の生体の 特定部位における作用を検証することが可能であ る。また, 内分泌擋乱化学物質を評価する上での 優先順位の設定や内分泌擋乱作用の機構解明にも 有効である。従って, 各in vitro 試験の有効性を知 り，うまく活用していくことが重要である。

\section{参考文献}

1) 手嶋勇人，伊藤高明：木材保存，20，93-99 (1994)

2) 藤本いずみ: 木材保存, 25, 121-129 (1999)
3）(社) 日本木材保存協会: 木材保存㓮ガイドライン (1994)

4) T. Colborn, D. Dumanoski, J.P. Myers: Our Stolen Future: Are We Threatening Our Ferility, lntellingence, and Survival? - A Scientific Detective Story. New York Dutton (1996)

5) 金子秀雄, 庄野文章, 松尾昌季: 科学, 68, 598605 (1998)

6) 金子秀雄: 周産期医学, 29, 399-402 (1999)

7) 金子秀雄: エコインダストリー, 4, 20-27 (1999)

8) 米国ホワイトハウス科学委員会: スミソニアン・ワ ークショップ (1997)

9) 加藤茂明: “核内レセプターと情報伝達”，実験医学 バイオサイエンス，羊土社，(1994）

10) S. A. Oñate, S.Y.Tsai, M.-J.Tsai and B.W. O'Malley: Sience, 270, 1354-1357 (1995)

11) H.Chen, R.J.Lin, R.L.Schiltz, D. Chakravarti, A. Nash, L. Nagy, M.L. Privalsky, Y. Nakatani and R.M.Evans: Cell, 90, 569-580 (1997)

12) A.M. Brzozowski, A.C.W. Pike, Z. Dauter, R.E. Hubbard, T. Bonn, O. Engström, L, Öhman, G.L.Greene, J.-̈̈.Gustafsson and M. Carlquist: Nature, 389, 753-758 (1997)

13) A.M.Soto, C.Sonnenschein, L.K.Chung, M.F. Fernandez, N.Olea and F.Olea Serrano: Env. Health Persp., 103, 113-122 (1995)

14) R.B.Dickson and M.E.Lippman: Endocr. Rev., 16, 559-589 (1995)

15) M. Villalobos, N.Olea, J.A. Brotons, M.F. Olea-Serrano, J.M.R.de Almodovar and V. Pedraza: Environ. Health Prerspct., 103, 844 -850 (1995)

16) J.Nishikawa, K.Saito, J.Goto, F.Dakeyama, M.Matsuo and T.Nishihara: Toxicol. Appl. Pharmacol., 154, 76-83 (1999).

17) L. Markiewicz, J.Garey, H.Adlercreutz and E. Gurpide: J.Steroid Biochem. Mol. Biol., 45, 399-405 (1993)

18）斎藤幸一, 富ヶ原祥隆，磯部直彦，金子秀雄，中塚 厳, 西原力, 第26回日本トキシコロジー学会学術年 会要旨集, 171 (1999)

19) K.Saito, K.Sumida, Y.Tomigahara, N.Ohe, N.Isobe, I. Nakatsuka and H. Kaneko, The Toxicologist, 54, 234-235 (2000)

20）住田佳代，斎藤幸一, 磯部直彦, 金子秀雄, 中塚厳, 
第26回日本トキシコロジー学会学術年会要旨集,

172 (1999)

21) 西原力: 日本食品化学学会第 9 回食品化学シンポジ ウム講演要旨集, 7-24 (1998)

22) 西原力: 安全工学, 38, 85-92 (1999)

23）住田佳代，大江師久，松永治之，金子秀雄：日本内
分泌擋乱化学物質学会第 1 回研究発表会講演要旨集, 11 (1998)

24）住田佳代，大江師久，斎藤幸一，磯部直彦，金子秀 雄, 中塚篇, 第 2 回日本内分泌擋乱化学物質学会研 究会講演要旨集, 93 (1999)

(2000.6. 8 受理) 